\title{
Migration and Sex Work through a Gender Perspective
}

\section{Charlotte Valadier*}

\begin{abstract}
The trajectories of migration and prostitution are embedded in representations of body, gender, sex and sexuality. This article seeks to understand the articulation between migration and sex work through the lens of gender. To this end, this article relies on a typological approach that aims to clear some ground in the ongoing debate on the issues of prostitution, sex trafficking and migration of sex workers. It explores the theoretical cross-contribution as well as the conceptual limitations of radical, liberal, post-colonial, critical and postmodern feminist perspectives on the issues of prostitution, sex workers' mobility and sex trafficking. It gives special focus to the contributions of the postmodern feminist reading, especially by highlighting how it has challenged conventional feminist theories, hitherto grounded in dualistic structures. In fact, the postmodern feminist approach makes a stand against the simplistic dichotomies such as First/Third World, passivity/ agency, vulnerability/empowerment, innocence/conscience, sexual trafficking/voluntary prostitution or 'trafficked victim'/'autonomous sex worker'. As such, postmodern feminism disrupts all fixed demarcations and homogeneous forms of categorisation on which the dominant feminist theories were based, allowing thus for the emergence of new practices of subjectivity as well as new forms of flexible identities.
\end{abstract}

Keywords: Migration; Sex Work; Sex Trafficking; Gender; Postmodern Feminism.

\section{Introduction}

When one talks about transnational prostitution or trafficking in persons for the purpose of sexual exploitation, the terms 'prostitutes' and 'sex workers,' 'prostitution' and 'sex trafficking' are often wrongly equated. The meanings of these words, and the political-subjective impacts they cause, may lead to radically different mechanisms of identification and analysis of the problem of the sex workers' mobility. Therefore, studying the interconnection between migration and sex work requires a systematic analysis of the mechanisms of production of the categories of 'sex work', 'prostitute,' 'migrant sex worker' and 'trafficked victim.' Investigating the categorisation processes at stake is thus a fundamental first step for any research study on migration, prostitution, and sex trafficking.

\footnotetext{
* Pontifical Catholic University of Rio de Janeiro (PUC-Rio), Rio de Janeiro-RJ, Brazil; charlotte.valadier@ gmail.com. ORCID iD 0000-0001-8517-9270.
} 
Sex work is the exchange of sexual services or performances for financial or material compensation, including activities of direct physical contact between buyers and sellers as well as indirect sexual stimulation. Because of the agency associated with the term, 'sex work' generally refers to voluntary sexual transactions; thus, it does not refer to sex trafficking and other coerced or non-consensual sexual transactions. By 'migrant sex worker', we refer to anyone who has left their country of origin to go to another place, either through formal or informal ways, and works in the sex industry. Finally, when we talk about 'migration for sex work', we refer to a migration project whose purpose is to enter into a globalised sex work market. In many cases, these migrants were already working in the sex industry in their home country and wished to migrate to richer areas in order to increase their income.

There is a general tendency to conflate the phenomena of 'migration for sex work' and 'sex trafficking.' According to Natália Ledur Alles and Denise Cogo (2017), this inclination to merge migration of sex workers and sex trafficking stems from a moral and conservative perspective that considers prostitution invariably a form of exploitation. This equivalence between migration in search of sex work and international trafficking in persons for the purpose of sexual exploitation contributes to reinforcing the stigmatisation and marginalisation of the subjects involved in the transnational sex industry (Alles and Cogo 2017). Thus, it is crucial to distinguish between the concepts of 'migration of sex workers' and 'sex trafficking' not only in order to understand their own specificities, but also to unveil the implications of the meanings that are attributed to them in the political discourses and practices of struggle against trafficking in persons.

The practice of 'sex trafficking' or 'trafficking of persons for the purpose of sexual exploitation' makes reference to the first international agreement on the definition of trafficking, found in the UN Convention Against Transnational Organized Crime (2000). It states that

'[t]rafficking in persons' shall mean the recruitment, transportation, transfer, harbouring or receipt of persons, by means of the threat or use of force or other forms of coercion, of abduction, of fraud, of deception, of the abuse of power or of a position of vulnerability or of the giving or receiving of payments or benefits to achieve the consent of a person having control over another person, for the purpose of exploitation (Trafficking Protocol, art. 3).

In this definition the term 'exploitation' encompasses sexual exploitation, forced labour, slavery, servitude and removal of organs. However, this paper focuses on the trafficking of persons for sexual exploitation.

The issue of migration of sex workers is strongly permeated by a gender dynamic. The trajectories of migration and prostitution are impregnated by representations of body, gender, sex and sexuality. In that sense, it is necessary to analyse the articulation between sex workers' migration and gender, exploring the mobility not only of women prostitutes, but also of feminised subjects, such as transvestites or trans-gendered people. 
Generally, feminist approaches seek to overcome and reconfigure the limits of International Relations as a field by questioning how gender is present in this discipline. Feminist perspectives adopt a critical view of International Relations, considering this area not only as a space that reflects and reproduces hierarchies of power, but also as a field of struggle for political control and for the contestation of legitimacy. In addition, feminist scholars aim at making women more visible in International Relations by challenging the theoretical models that were supposed to be 'neutral,' as well as politicising many themes traditionally seemingly unquestioned. Through a deep analysis of the meanings attributed to the concepts of 'femininity' and 'masculinity' and logics of internalisation of the social hierarchies produced by the patriarchal system, feminist approaches bring to light global inequalities based on sex and gender. Therefore, feminist perspectives question the structuring effects of different forms of power, which until then looked naturalised (Enloe 2004).

Feminist studies on issues of transnational prostitution and migration of sex workers have been stuck in a 'sex war' (Weitzer 2007) between two opposing currents: radical or abolitionist feminism, which associates prostitution and sex trafficking with violence and slavery against women, and liberal feminism, which stresses women's freedom to control their own bodies, the empowerment of sex workers, and the regularisation of prostitution. However, from the 1990s, the controversy has taken on another dimension, because of the emergence of the postmodern feminist movement. In fact, the postmodern approach opens the debate beyond the simple dispute over the issue of consent, transcending the issue on the simplistic dichotomy between the 'passive trafficked victim' and the 'autonomous sex worker' at the basis of the hitherto division between radical and liberal feminists.

Postmodern feminism developed in the early 1990s with the works of Judith Butler $(1990,1993)$ as an alternative discourse to the universalistic and totalising narratives promoted by radical and liberal feminism. The movement questions and deconstructs modern concepts related to sex, gender, and sexuality by considering that such concepts are not neutral, but rather social constructs used to maintain and reproduce gender roles and hierarchies. By focusing on the social and discursive construction of otherness, postmodern feminist approaches reject the idea of sex or gender identity as predefined or fixed. Bodies and sexes are not understood as natural or biological phenomena, but as performance processes in which sexual and gender identities are constantly affirmed and reactivated by power structures.

Moreover, postmodern feminists question the production of the meaning of what is understood as being a 'woman' as well as the political implications of this understanding (Butler 1990). In that sense, the postmodern feminist perspective differs from other feminist approaches, since its fundamental purpose is not to free women from oppressive identities, but to study the mechanisms of power that shape the identity of women (Zalewski 2000).

According to postmodern feminism, the identities of social groups are determined by the inequality of their interrelationships. For postmodern scholars, dominant discourses tend to reflect and reiterate hierarchical social relations by constructing narratives that 
rank countries and subjects on a scale of modern values. In this context, we can note that dominant abolitionist discourses on prostitution and sex trafficking are based on a dualistic rhetoric, which values and idealises certain types of activity or subject to the detriment of other types that get conversely denigrated. For example, the writings of Kathleen Barry $(1984,1995)$ have been criticised by postmodern feminists for outlining a discourse on modernisation which attributes the distinction between sex trafficking and autonomous prostitution to the development levels of countries (Pickup 1998). Indeed, this kind of discourse is built on a hierarchy of social and economic progress that places sex trafficking at the most primitive stage of development. According to this view, on the one hand, sex trafficking becomes the archetype of preindustrial societies, in which women are considered as the exclusive property of men and thus excluded from the public sphere. On the other, at the other end of the spectrum, autonomous prostitution is associated with post-industrial developed societies, in which women achieve a high level of economic independence and social freedom.

Likewise, the distinction between voluntary prostitution and sex trafficking is based on a division of race and class among sex workers (Pickup 1998). The depreciated stereotype of the passive, poor and naive migrant prostitute is framed as opposed to the idealised stereotype of the active, skilled and self-aware western 'sex worker' (Doezema 1995). By portraying non-western women as impotent and vulnerable victims, dominant discourses on sex trafficking continue to designate western women as a reference point for the modern, educated, and emancipated femininity (Mohanty 1991). Therefore, such dichotomies, namely First/Third World, rich/poor, white/black, active/passive, voluntary/ forced prostitution, are various modes of demarcation of women regarded as 'different' (Andrijasevic 2004).

Taking these considerations into account, this article will use the lens of gender to analyse the phenomenon of migration of sex workers and its relations and distinctions from the phenomenon of 'sex trafficking.' Its purpose is to expose the typology of the different theoretical approaches that feed into the ongoing debate on the issues of prostitution, sex workers' migration and sex trafficking. To this end, I will map the logic and arguments of different feminist perspectives - radical, liberal, post-colonial, critical, postmodern and queer - by examining their similarities and differences and appraising their strong points as well as their conceptual and theoretical limitations. Hence, this article seeks to understand the contributions and articulations between these different feminist schools of thought, that is, how they may dialogue with, intersect, and confront one another. In this way, the mutual interconnection and cross-contributions of the different feminist approaches will be explored throughout the text as well as their nuances.

The first part of this article will deepen the arguments of radical and liberal perspectives on this problematique, in particular by emphasising their divergence when it comes to the conception of sexuality, sex workers' agency and regulation of the sex work market. While radical abolitionist feminists see migrants exercising prostitution in Europe through the lens of victimisation, sexual exploitation and oppression of women by patriarchy, liberal feminists, in turn, consider them as empowered sex workers who are able to 
claim rights to free movement and demand the legalisation of sex work. Such conceptual ruptures have considerably hampered the dialogue between the different theoretical approaches within the feminist movement.

Yet, with the advent of post-colonial and critical feminist perspectives, contemporary debate on prostitution and sex trafficking has brought the debate beyond the 'sex war' between the radical and the liberal by considering new elements of analysis. Hence, the second part of this article highlights the theoretical contributions of post-colonial and critical feminism on the issue of sex workers' migration, emphasising its purpose to deconstruct the simplistic categories that have so drastically divided radical and liberal feminists in traditional literature. By disrupting oversimplified categorisations and dichotomous separations which the 'sex war' has been based upon (Weitzer 2007) and integrating the multiple interactions between race/ethnicity, class and culture, these new approaches have contributed to a better understanding of the complexity of the link between migration and sex work. An analysis of the converging and diverging points between critical and postcolonial feminist theories will be also developed.

The third and last part of this article will address the contributions of postmodern feminism to the issues of prostitution and international migration of sex workers. The queer perspective developed in the 1990s with the crucial purpose of deconstructing every homogenising identity demarcation and opening up the path to new forms of flexible or negotiable identities. By questioning the social regulation of sexuality and the production of labels on sexes, the queer reading advocates for the diversity, difference and plurality of sexual identities. As such, queer theory has become essential for the emancipation of sex workers from dominant social and sexual ideologies. In addition, it has destabilised the boundaries and hierarchies which circumscribe the social meanings associated with the global mobility of migrants who work in the transnational sex industry.

\section{'Sex trafficking victim' or 'empowered sex worker'? The 'sex war' between radical and liberal feminism}

\section{The radical abolitionist feminism: prostitution and sex trafficking as modern slavery}

Since the 1980s, abolitionist studies have dominated the most part of contemporary literature on prostitution and sex trafficking. The first radical feminist wave was based on a discourse of sexual domination, arguing that prostitution is a categorical form of oppression and of social subordination of women (Shrage 1997). For these radical scholars, prostitution is synonymous with sexual slavery, given that they frame prostitution and sex trafficking in terms of a violation of women's human rights. Therefore, the abolition of prostitution is considered the necessary condition to stop sex trafficking.

In 1984, Kathleen Barry, Charlotte Bunch and Shirley Castley (1984) launched International Feminism: Networking Against Female Sexual Slavery, which in 1988 became the Coalition Against Trafficking in Women (CATW) (2011), the leading abolitionist organi- 
sation in the fight against trafficking in women. These activists reject the idea of choice or free will defended by the liberal feminists, since they consider that prostitution is forced by definition. Likewise, Kathleen Barry, in her book Female Sexual Slavery (1984), refuses to separate sex trafficking from prostitution, arguing that both of them constitute a form of violence against women. According to this view, prostitution, like rape, genital mutilation or incest is regarded as a form of sexual exploitation. In fact, radical feminists consider that sex is objectified, that is, transformed into a commodity to be sold and bought in the sex industry market. Through the act of prostitution, the woman is reduced to a sexual object at the disposal of men, which destroys her human dignity. Hence, this approach presumes that the act of sexual exploitation is harmful in and of itself, because it is based on abuses and on mechanisms of dehumanisation.

Therefore, by affirming that prostitution harms women and that legal prostitution markets facilitate sex trafficking, radical feminists oppose the institutionalisation of sex work (Jeffreys 2005). In Kathleen Barry’s (1995: 36) words:

Normalizing the sexual exploitation of women does not make it less sexually exploitative; it only makes it more easily available. In fact, when women are encouraged to incorporate within themselves, into their identities, the knowledge of themselves as socially acceptable sex objects, the damage of prostitution, or of any sexual objectification, is intensified.

According to Carole Pateman (1988), the sexual contract, by which women sell their own bodies in the sexual market, is based on a fictional notion of consent. Indeed, radical feminists think that prostitution is fundamentally wrong, because as such, it turns the body into a commodity, thereby alienating it from the 'self.' The sexual use of the body through the prostitution contract requires that the woman alienates the integrity of her body from her 'self', which generates serious physical and physiological consequences (Jeffreys 1997; Barry 1995). Carole Pateman (1988) argues that 'there is an integral relationship between the body and the self. The body and the self are not identical but selves are inseparable from bodies' (Pateman 1988: 207). For her, the contracting of the use of the body is different from other forms of employment, since the prostitute dissociates herself from her sexuality and femininity. In order for the client to buy the right to ownership of her objectified body, the prostitute must sell herself in a much more real sense than in any other type of work, which consequently requires her to develop strategies of disembodiment or distancing from herself. In the words of Carole Pateman (1988: 207):

Women's selves are involved in prostitution in a different manner from the involvement of the self in other occupations. Workers of all kinds may be more or less 'bound up in their work', but the integral connection between sexuality and sense of the self means that, for self-protection, a prostitute must distance herself from her sexual use. 
The radical feminist approach makes the case for an in-depth study on male violence and appropriation of female sexuality since, to them, this is of fundamental importance for a better understanding of the phenomena of prostitution and sex trafficking. Indeed, male domination is a form of control that operates in the production and reproduction of hierarchical gendered relations in society. Radical feminism points out that both prostitution and sex trafficking are underpinned by economic, political and social inequalities between men and women. Such a viewpoint provides a strong argument that links the sexist and sexualised nature of these phenomena with the modern patriarchal system. Here, North/South inequalities and the subordinated status of women are designated as the structural causes of this system of 'modern slavery' (Hughes 2000).

Furthermore, radical feminism identifies victims of sex trafficking by their sociological characteristics. Portrayed as poor and naive women, such victims are perceived in this context as being in need of help to be rescued from slavery and reintegrated into a new life, free from prostitution. This discourse of moralisation and victimisation is based on a typical image of the migrant sex worker as a vulnerable and passive victim who needs to be assisted and protected by social workers (Pickup 1998; Berman 2003; Jahic and Finckenauer 2005).

However, the radical feminist stance has received strong criticism from sex worker activists, since it tends to essentialise sexuality and the relationship between the sexual act and self-identity. Sex workers argue that sex work is not necessarily the only activity around which their identities are defined (Kempadoo and Doezema 1998: 3). This criticism by sex workers follows from the argument that radical feminism ignores the variety of meanings and the changes in perceptions and values that women have over their own sexual lives. In addition, the radical approach underestimates the fact that criminalisation regimes could contribute to the marginalisation of sex workers.

Moreover, the radical feminist approach runs the risk of understanding women as a homogeneous impotent group, that is, a group of constant victims of the socio-economic and political system. In fact, such an approach does not differentiate women's experiences according to their class, race or age (Andersen 2005). By placing active male aggressors in the position of control and dominance, radical abolitionist feminism is grounded on the assumption that victims are in a passive state (Pickup 1998: 1009). It is on the basis of this last observation that liberal feminists develop a vehement criticism of abolitionist discourses.

Finally, liberal feminists denounce the association made by radical feminists between migration for sex work and sex trafficking. Instead of addressing all migrant sex workers as victims of sexual trafficking, liberal feminists consider that some of them could be seen as active and rational actors, endowed with the power of consent and able to formulate political claims. In this new liberal point of view, migrant sex workers would also have the ability to organise themselves into groups and formulate political demands, whether in terms of regulation of sex work or in terms of labour, social and free movement rights. 


\section{Liberal feminism: rights and empowerment of sex workers}

The liberal tradition conceives human beings as rational agents and defends an individualistic conception of human nature. It follows from the reasoning that, being endowed with reason, individuals have the capacity to think and act rationally and are therefore able to affirm their personal choices in an autonomous way. For liberal feminists, in order to achieve gender equality, the legal and institutional barriers that impede women's access to the same rights and positions of power as men need to be removed (Tickner 2001: 12). For this reason, equal rights and equal access to education and economic opportunities become priorities of the liberal feminist struggle. From the liberal point of view, the underrepresentation of women in politics stems from the processes of socialisation and education that occur in a differentiated way between men and women on the one hand, and from the legal restrictions that limit women's freedoms and rights on the other. Thus, the generalized domination of men over women is seen as a consequence of an institutional imbalance.

Since the late 1990s, an extensive liberal feminist literature has emerged in response to the 'victimising' perspective of abolitionist feminism. Liberal-inspired feminists and sex worker activists have started to conceptualise prostitution as a form of 'work' (Perkins 1991). Advocates of the liberal view, most of the members of the Global Alliance Against Trafficking in Women (GAATW) (n.d.) and the Network for Sex Work Project (NSWP) the two rival organisations of the Coalition Against Trafficking in Women (CATW) - state that only the use of force can be used as a criterion for defining a trafficking situation for purposes of sexual exploitation. Indeed, according to liberal feminism, the radical reading denies the agency of women who enter the sex trade on a voluntary basis. Instead, the liberal perspective emphasises the freedom and personal choice of most sex workers (Kempadoo and Doezema 1998).

This pro-sex labour perspective is centred on the notions of agency and empowerment and refers to the capacity of social actors to transform the power relations in which they are inserted, as well as to reorient the discourse on sex work to frame it as positive (Outshoorn 2004). In contrast to the image of the female victim described in the abolitionist discourses, this new approach portrays the figure of the female sex worker as an active subject, able to negotiate and claim political rights. In this context, female sex workers are conceived as self-determined individuals capable of transforming the power relations rooted in institutions such as family, home, marriage, the labour market, slavery, or prostitution (Kempadoo 2005: 61).

Furthermore, liberal feminists denounce the paternalistic nature of international and national programmes aimed at fighting trafficking in persons for the purpose of sexual exploitation. Thus, liberal feminists advocate for the decriminalisation of prostitution markets because they consider that both repression of prostitution activity and restrictive migration policies are, in fact, responsible for the subordination of women (Augustin 2007). In this sense, they condemn abolitionist laws on the grounds that they put sex workers into situations of greater risk of violence and exploitation (Wijers 1998). According to Anne McClintock (1993), sex workers often find themselves unable to report dangerous 
clients, violent pimps, or rape cases to the police out of fear of being exposed to risks such as prison, exorbitant fines, deportation from national territory, loss of custody of their children, confiscation of their personal property, or eviction from their dwellings, among many others.

The basic claim of liberal activists is that sex workers should have the right to exchange sexual services on their own terms and conditions (McClintock 1993). Such a perspective defends the possibility of these workers negotiating precisely the time, nature and prices of specific services they wish to offer, without any intrusion of the state, police, pimps, or customers. They also demand respect and dignity in their work, claiming the right to exercise their activity in safe and healthy conditions, and to organise themselves collectively as professionals.

Removing sex workers' fundamental right to choose - whether to work, how to work, when to work, and where to work - is a flagrant infringement of their basic working rights, their integrity, and their humanity, not a universal and inherent feature of the sexual exchange (McClintock 1993: 4).

However, the current of liberal feminism also has significant weaknesses. Firstly, the idea that women share the same qualities and competences as men presupposes that the standard of male behaviour is the goal to be achieved at all costs for women. Moreover, liberal feminists tend to analyse gender inequalities separately from issues related to social class, race/ethnicity, age, and culture. This last point has been criticised by post-colonial feminists, whose main objective is precisely to identify and analyse social relations under global capitalism in all of its forms, that is, by studying its national, racial, ethical, class and gender aspects (Limoncelli 2009).

\section{Beyond the 'sex war': complexity and multidimensionality}

\section{Post-colonial feminism: intersectionality between race, class and gender}

Between the late 1970s and the early 1980s, the meeting between feminism and postcolonialism brought important contributions for the discipline of International Relations. Post-colonial feminism emerged as a reaction to the feminist theory as developed in the USA and Europe by questioning its essentialised representation of 'Third World' women. Southeast Asian, African, Latin American and African American academics and activists started to blame 'First World' feminism for ignoring the local experiences, motivations, customs and demands of such non-western subjects of study (Bazzano 2016).

Through a critical interpretation of the texts and discourses of western feminist discourses and bringing to the forefront the experiences of women of colour, of ethnic minorities, and of Third World migrants, post-colonial feminism has contributed to destabilising the theories thus far consolidated. By echoing several feminist critiques of capitalism and patriarchy, post-colonial feminist studies highlight the roles of racism, colonialism, and 
neo-colonialism in the oppression of women of colour (Peterson and Runyan 1999). From this standpoint, international sex trade is hence understood as a force that capitalises and reinforces the hierarchies of gender, race, and nationality.

Moreover, post-colonial feminists denounce the colonial discourses and practices of western feminists due to their presumption of wishing to 'save' or 'enlighten' women from the global South, especially by constructing a negative image of the innocent and vulnerable trafficked victim from Third World countries (Berman 2003; Jahic and Finckenauer 2005). For post-colonial scholars like Kamala Kempadoo $(1998,2005)$ and Jo Doezema $(1995,2004,2011)$, the abolitionist approach - which influences most of the official documents on migration, prostitution, and trafficking issues - portrays women from the global South as submissive, ignorant, poor, low-educated and of problematic social and family background. Another characteristic of the western anti-trafficking discourses highlighted by post-colonial feminists is their tendency to infantilise migrant sex workers (Doezema 2004). By associating them with children, they implicitly reinforce the idea that their migration project in order to work in the sex industry in Europe cannot be the result of a mature, conscious and autonomous decision, but instead can only result from a lack of judgment due to their young age (Osborne 2004). The fact that they compare migrant prostitutes to children, irresponsible under law provisions, evidences the general understanding of immigrant women as naive and incapable of being responsible for their own destiny on the basis of rational criteria. According to this argument, because they can be easily manipulated, these women would need protection by states.

Generally, migrant prostitutes from developing countries are portrayed by dominant Eurocentric discourses as exotic and rare, as opposed to the white European sex workers. Here, the act of describing them on the basis of weird ethnic, racial and sexual characteristics can be understood as a strategy that serves to differentiate such immigrants from the category of 'European sex workers.' For example, Adriana Piscitelli (2007), in her study on Brazilian sex workers in Spain, points out that Brazilian prostitutes are depicted not only as loving and caring women, but also as sensual and erotic, that is, as if they were naturally over-sexualised. As such, erotic, aesthetic, and sexual attributes are built on a racial differentiation: the particular femininity assigned to Brazilian women is directly linked to their darker skin tone. Here, the notion of 'miscegenation' can partly explain the attraction for Brazilian women's sensuality (Piscitelli 2007, 2013; Silva and Blanchette 2005). On top of that, Brazil is perceived in the common representations as the country of folklore, carnival and liberalisation of sexual intercourse (Silva and Blanchette 2005). Thus, Brazilian women live with a peculiar corporal stereotype, linked to the construction of a national identity. The historical mythical concept of the 'Brazilianness' shapes the Brazilian woman as sensual and always inclined to sexual experiences, which unveils a clearly Eurocentric and colonial character (Silva and Blanchette 2005). Therefore, these studies reveal how Eurocentric attributions prescribe the notion of a racialised and sexualised 'other'.

In general, these 'other' women, from ethnicities, races, cultures and societies outside the western world are designated as defenceless, uneducated, sexualised and subjected to traditional gender models. In the context of sexual trade, such categories of 'colour, 
culture, religion, origin and race are used to exclude, inferiorise and exploit the other' (Mayorga 2011: 330). Sexualisation of race and ethnicity is an integral part of the game of power relations and exclusion, namely between European citizens and aliens, between European and immigrant women, or between white and coloured women.

These discourses reflecting Eurocentric viewpoints have strong repercussions on the way the programmes and policies to control the crime of trafficking in persons for the purpose of sexual exploitation are oriented and prescribed. In fact, the supposed naivety and vulnerability of the migrant prostitute serves as an argument to identify them as 'threats' due to their high probability of being deceived, recruited and trafficked by transnational criminal networks. The 'other' women, seen as 'victims', are thus reduced to passive subjects of the imperialist interventions of First World countries. In the contemporary debates about sex trafficking, the voices of the native victims become thus irrelevant; they are thus substituted by the voice of the colonial helper who formulates political strategies to regulate their bodies and movements. In the words of Laura Augustin (2005),

[T] he protagonists in debates on 'trafficking' are first-world citizens, not migrants, and migrant women are routinely characterized as pushed, obligated, or coerced, even when they travel for the same reasons as men: to expand their horizons and get ahead through work (Augustin 2005: 107).

The post-colonial feminist perspective and critical theory are strongly linked, since they share strong critical principles. Even if critical theory may be identified as either deeply rooted in European experiences, as uninterested in non-Eurocentric forms of emancipation and as problematically aligned with traditional notion of progress, both theories are based on the deconstruction of mainstream discourse. In fact, just as postcolonial theory makes a deconstruction of the colonial discourse, highlighting the implicit racism and eurocentrism hidden throughout its narrative, the critical approach deconstructs the rhetoric and grammar that are strategically used by the dominant discourse on prostitution and sex trafficking by showing that they reflect pre-existing political and social purposes and interests, rather than neutral narrative stated by impartial subjects engaged in an objective reality.

\section{The critical feminist approach: deconstruction of simplistic categories}

Critical studies on the articulation between migration and prostitution aim to demonstrate how the instrumentalisation of the figure of migrant prostitutes in Europe is part of a discursive strategy that serves to legitimise public intervention, especially in matters of migration policy. According to critical scholars, in order to allow for a more appropriate and multifaceted description of the issue of prostitution, it is crucial to distance oneself from simplistic and uniform representations of the trafficked women as helpless and irresponsible 'victims' (Berman 2003). This movement of deconstruction allows a distancing from the 'discourse of salvation' of the abolitionist approach, which portrays migrant 
prostitutes as passive, poor, naive, deceived and manipulated by barbarous traffickers, thus opening the way to introduce an alternative vision which in turn highlights autonomy and political action (Silva, Blanchette and Bento 2010).

The critical approach privileges the voice of the main subjects involved in international migration and sexual trafficking. Rather than focusing on sociological profiles or on personal characteristics of sex trafficking victims, this counter-hegemonic stance emphasises a case-by-case study in order to highlight each subjective experience. Through deconstructive ethnographic studies, critical authors try to identify the gaps between dominant discourses on sex trafficking and the real experiences and lives of the individuals for whom the anti-trafficking programmes are directed. By adopting methods of participant observation and semi-structured interviews with the subjects categorised as 'victims of trafficking', the purpose of critical theorists is to detect the discrepancies between the official rhetoric about sex trafficking and the plural reality of migration and sex work (see Andrijasevic 2005; Mayorga 2011; Piscitelli 2007, 2013).

The aim is to deconstruct the restrictive and homogenising category of 'trafficking,' since it tends to make the autonomy of migration invisible and depoliticised. Thus, by accounting for the stories of migrant women, it becomes possible to reveal the complexity of their life project, which goes beyond the mere goal of working in the sex industry. This allows us to shed some light on a much more heterogeneous reality, made up of migratory choices, plans and desires. Therefore, the critical viewpoint helps to pave the way for the emergence of singular stories that highlight the active role of individuals within their own migration trajectory (Andrijasevic 2005).

Adriana Piscitelli (2007), in her study on the Brazilian community engaged in the sex industry in Spain, emphasises that, contrary to dominant representations, most of them had already offered some sexual services in Brazil and migrated with this goal in mind. Consequently, many Brazilian migrants were aware of the type of work that awaited them in the destination countries. According to Rutvica Andrijasevic (2004), prostitution could be seen as an integral part of the migration project, that is, as an indispensable step through which people intend to create new life opportunities. In this context, prostitution provides a feeling of emancipation in the sense that it allows migrant sex workers to reach economic independence. The stability offered by a regular income gives to migrant prostitutes more autonomy to impose their desires, opinions and ways of life away from possible violent or authoritarian partners (Mayorga 2011: 342).

Therefore, critical scholars draw attention to motivations for migration that include personal issues and desires. They point out that beyond the economic criteria, many individuals wish to migrate in order to explore famous places, discover other cultures, meet new people, or even to get married (Augustin 2005; Mayorga 2011; Piscitelli 2007). In such circumstances, travelling to Europe could be interpreted as an aspiration for cultural evolution or a desire for freedom and for widening their life horizons.

In addition, critical feminist scholars examine the notion of 'help' or 'assistance' in women's migration projects and argue that migrant processes are often financed and supported through family and community networks (Augustin 2005; Mayorga 2011; Piscitelli 
2007; Silva and Blanchette 2005). The critical approach dismantles the stereotype of the involvement of international criminal networks behind sex trafficking. According to the critical viewpoint, instead of being enabled by organised mafias, the migration projects are actually promoted by informal small-scale networks, made up of friends, neighbours or relatives. Thus, in these circumstances, the third parties involved in immigration processes are not necessarily powerful and barbaric groups or members of organised crime networks.

Finally, another critique refers to the elements of coercion and manipulation by criminal groups that are often pointed out by the conventional anti-trafficking discourse. Instead of describing their relationship with traffickers as abusive, most trafficked women identify the recruiters as persons who could provide them with a job opportunity abroad (Augustin 2005). These examples show how, through the critical feminist lens, the homogenising assumptions about trafficking in persons for the purpose of sexual exploitation can be deconstructed.

Ultimately, critical feminists clearly denounce the tendency of the radical feminist approach to associate all sex worker migrations with sexual trafficking. By showing the limitations of such conflation in the face of the subjective experiences and practices of migrants who engage in prostitution in Europe, the premises of the radical abolitionist discourse are thus called into question.

\section{The postmodern feminist perspective: resistance against hegemonic norms}

\section{The queer reading of sex work: challenging heteronormativity}

One of the main criticisms from the queer perspective directed at mainstream feminism is that the latter has been concerned exclusively with gendered relations within a heterosexual structure. In that sense, radical and liberal feminists are accused of promoting a pattern of 'heteronormativity' (Butler 1993) that pressures individuals to follow heterosexual norms of relationship. According to the queer perspective, by focusing only on an essentialised pattern of affective and sexual relations between men and women, conventional feminism contributes to the exclusion and marginalisation of individuals whose sexual orientation is different from the heterosexual standard. Moreover, it is argued that a conventional reading such as this takes 'identity' as a given and not as a problematised category. Instead, queer theory breaks with binary categorical forms of identity, such as 'male'/'female' or 'heterosexual'/'homosexual' by arguing that 'sexual identities, desires, and categories are fluid and dynamic' (Gamson and Moon 2004: 49).

Focusing on sexes and genders as objects of study, queer theory deals with 'non-monolithic' sexualities (Weber 2004), such as homosexuals, lesbians, bisexuals or transgender individuals. However, we have to note that the tendency to equate queer with LGBT is misplaced, since it reduces the term 'queer' to the description of non-heterosexual iden- 
tities. In other words, it treats it as if it were a mere term of inclusion. Instead, the term 'queer' does not refer to an essence, whether of a sexual nature or not.

As a result, queer politics highlights the impossibility of inclusion (Chambers 2009; Philips 2009). According to David Halperin (1995), the term 'queer' acquires its meaning in opposition to the norm: 'Queer is by definition whatever is at odds with the normal, the legitimate, the dominant. There is nothing in particular to which it necessarily refers. It is an identity without an essence' (Halperin 1995: 62). Indeed, the negative relation of queer politics consists in a subversive resistance against the normative hegemonic categories of gender and sexuality. Therefore, queer politics is anti-normative, anti-conformist and anti-assimilationist. According to Nicholas de Genova (2010), 'Queerness (unlike 'homosexuality', for instance) audaciously asserts the existence of something fundamentally unintelligible, incommensurable, incompatible, and finally inassimilable. And indeed, what makes it political is the irreducible fact that it is incorrigible' (De Genova 2010: 109).

Thus, queer politics aims to overthrow hierarchical orders and abolish all kinds of normativity. In that sense, because it subverts the social regulation of sexuality, queer theory contributes to the liberation of sex workers from dominant social and sexual ideologies. Challenging the idea that there is a unified or fixed sexual identity, queer theory refutes the limitations usually associated with the 'sex worker' identity. Judith Butler (1990) argues that gender and sexual orientation are not static internal identities, but rather processes that are continually promulgated throughout the everyday life.

From this perspective, one can say that the sexual practices of sex workers are 'queer' insofar as they manifest a non-conformist form of freedom or a disruptive position against the socio-political order of a heteronormative patriarchy. The sex work can be seen as a 'performance of heterosexuality' that defies dominant arrangements of power (Pendleton 1997). Although the sex workers interpret a set of highly feminine codes to respond to male desires, the acting is performed according to their own terms. Sex workers deliberately invent new personalities, playing with attributes of femininity and male fantasies. The work of sex becomes then a 'parody of the heterosexual norm' (Read 2013: 475). While adhering to some norms of the hegemonic femininity, and at the same time violating others, sex workers destabilise binary gender ideologies and subvert the structures, rules, and customs of heteronormativity (Kay 1999).

The international sex industry is filled with contradictions and nuances which go beyond the binary and simplistic caricature between 'slave women' and 'dominant men.' In fact, the universe of prostitution is a space for gender conversion and transformation, where the complexity and ambiguity of sexual praxis can be manifested. In this sense, sex workers, like all other individuals, 'enact multiple, overlapping, intertwined, contradictory and simultaneous identity roles' (Read 2013: 244). To that extent, the queer movement enables the formulation of an alternative discourse that emphasises the multiple dimensions of sexuality and promotes the diversity and plurality of sexual identities (Creed 1994).

Furthermore, queer theory destabilises the boundaries that circumscribe the social meanings associated with the transnational mobility of migrant sex workers. When migrants enter the world of transnational prostitution, they experience new 'fractally queer' 
lifestyles, which emerge from the encounter between old and new personalities and gender regimes, thus creating new globalised sexualities (Mai 2012). The concept of 'fractal' is an intrinsically paradoxical concept that seeks to capture the ambivalence between irregularity (strangeness) and recurrence (normativity) or, in other words, between the fragment (the margin) and the whole (the conventional) (Mandelbrot 1982). For migrant sex workers, the migration process and the entrance into the global sex industry can be experienced as fractals, as they engage in practices and lifestyles that are at the same time irregularly alien and recurrently normative. Both experiences simultaneously reproduce and challenge the heteronormative trajectories of life and the patriarchal gender roles. In fact, alternating between compliance and transgression behaviours, they break the image of a unified personal and social identity, as coherent in terms of gender or profession. For Nick Mai (2014),

In many accounts, the sex industry emerges as intrinsically and ambivalently queer, compared to hetero- and homo-normative 'straight' lives and jobs. Because they live a double life between their 'straight' lives and jobs and the sex industry and their earnings from selling sex, many migrants develop a sense of spatial and temporal separation that allows them to 'escape' from normative everyday life (Mai 2014: 10).

Therefore, this oscillating movement between a 'straight' life at home and a 'deviant life' at work opens space for these migrants to negotiate different aspects of themselves, thus producing highly hybridized identities.

\section{The postmodern approach on migration and mobilisation of migrant sex workers: 'autonomy of migration' and 'acts of citizenship'}

The phenomena of migration and prostitution are shaped by both macro-level and microlevel forces. For this reason, it is crucial to study the interactions between hegemonic structures of gender, race and class domination on the one hand and individual acts of subjectivity on the other. It is precisely in the interstitial spaces between the systemic and the intersubjective scales that new impulses, resistances and movements which lead to social changes are produced.

According to the theory of 'autonomy of migration' (see Papadopoulos, Stephenson, Tsianos 2008; Mezzadra 2011), besides the external conditions that lead migrants to cross borders, such as persecution, poverty, disaster or conflict, migration projects are also the result of subjective decision-making processes that integrate individual, family and community strategies of survival. For Sandro Mezzadra (2011), it is essential to take into account 'the fundamental contribution that family and community networks make both to the dynamics of migration and to the integration of migrants in 'receiving societies' (Mezzadra 2011: 11). 
The theory of autonomy of migration draws attention to the practices of subjectivity that are expressed beyond objective causes. It is about integrating the macro-analysis the structural processes - with the micro-analysis - the individual subjective experience - within the study of the migration (Mezzadra 201: 8). Migration is conceived as a creative force, shaped both by the practices and desires of autonomous subjects and by social, cultural, and economic structures. According to this theory, the migratory impulse is uncontrollable since it always precedes or exceeds any political attempt of border control. In the words of Anne Mc Nevin (2013), 'From an Autonomy of Migration perspective, migrants are the origin of a creative force that exceeds and/or precedes sovereign control and institutes new social relations' (McNevin 2013: 193).

To use the perspective of the autonomy of migration could help us to conceive the presence of the migrant female sex worker not in terms of 'victimhood' but in terms of 'subjectivity', hence making way for the expression of innovative practices of resistance and struggle. Special attention should be paid to the subjective practices, expectations and wishes of the migrants working in the sex industry. In a context characterised by poverty and by the need for survival, 'making money' is a goal that allows young migrants to fulfil their desire to achieve psychological autonomy and upward social mobility (Mai 2014). Larissa Pelúcio (2009), in her study of Brazilian transvestites working in the sex industry in Spain, shows how prostitution is not only a means to earn money, but also a way to experience the 'glamour, that is, to have better access to European culture, to earn more respect for their gender, and to perfect their body's transformation.

The complex and sometimes contradictory subjectivities of young migrants are formed from an ambiguous interaction between the need for survival, aspiration for a hedonistic lifestyle, distancing from the family, and transformation of traditional models of authority (Mai 2014). For example, female migrants who occupy ambiguous and contradictory positions such as those of mother, daughter, victim, migrant or sex worker, simultaneously embrace, resist, and reshape existing representations of femininity and sex work (Mai 2014). It is within this complexity that elements of both vulnerability and resilience can be identified. As a consequence, migrant sex workers could not be identified strictly as victims or as sex workers.

Furthermore, postmodern authors have examined how political mobilisations of irregular migrant sex workers have challenged the concept of active European citizenship (Andrijasevic, Aradau, Huysmans and Squire 2012).

In October 2005, sex workers from twenty-eight countries met in Brussels to attend a demonstration. On that occasion, sex workers, including migrants, presented the Declaration of the Rights of Sex Workers in Europe (ICRSE 2005) to the European Parliament. This document was the result of a consultation with sex workers carried out by an International Committee based in the Netherlands. Among other things, this declaration calls for migrant sex workers, previously excluded from European citizenship laws, to have the possibility of obtaining the right to have rights. Through this declaration, sex workers, who had been marginalised for so long, gave higher visibility to their claims and constituted themselves as new protagonists of European citizenship. 
According to the postmodern approach, by including the right to free movement in their political demands, the 2005 mobilisation of sex workers challenged the traditional definition of Europe as a geographic and political predefined area (Andrijasevic, Aradau, Huysmans and Squire 2012: 506). In fact, this mobilisation questioned the legitimacy of European Union citizenship, up to then territorially and culturally limited to the European area. This cross-border political movement challenged the institutional framework of the European Union, as it called into question its classical definition of citizenship, which traditionally restricts access to rights to specific categories of citizens.

Since then, migrant sex workers have emerged as active, responsible and self-organising political subjects, thus broadening the conception of whose subjects could be perceived as legitimate political actors. In short, according to Rutvica Andrijasevic, Claudia Aradau, Jef Huysmans and Vicki Squire (2012), the actions and claims of the sex workers have contributed to moving beyond the limits in which active citizenship was established in the European Union, as well as to promoting a new form of European citizenship. According to these scholars,

[The sex worker's mobilization] simultaneously disrupts active citizenship in the institution of EU citizenship and by challenging the limitation of citizenship in its territorially and culturally bounded form. Sex workers enact a collective political subject that politicises exchange relations between strangers, thus detaching political being from communitarian and identitarian forms of bounds (Andrijasevic, Aradau, Huysmans and Squire 2012: 511).

By claiming the right to mobility of non-EU migrants, it can be argued that the mobilisation of sex workers in 2005 brought about a change in practices of mobility towards 'acts of citizenship' (Isin 2008). Engin Isin (2008) introduces the notion of 'acts of citizenship' to refer to the routines, customs and norms of everyday life through which subjects are constituted as citizens. This new approach undermines the very premises of modern citizenship, as it challenges the understanding of European citizenship as a legal status defined by states.

On that basis, the claim for rights by undocumented migrants can be conceptualised as an 'act of citizenship' (McNevin 2006; Nyers 2008; Squire 2009). While modern citizens continue to follow established patterns of political participation, migrant sex workers, through their mobilisation, have created new citizenship scripts and have self-constituted themselves as new political actors (Isin 2008). Therefore, by claiming labour and free movement rights, migrant sex workers were able to disrupt the established order, as well as to challenge and broaden the concept of citizenship, thus engendering new post-state cosmopolitan identities.

Since the early 2000s, an important body of literature has started to reconsider the subjectivity of irregular migrants, going beyond the logic of sovereignty and using notions such as 'abject' (Nyers 2003) or 'undesirable' subjects (Squire 2009). Because they are at the same time functionally disruptive and necessary for the international order, the 
complexity of the status of the irregular migrant sex worker could be understood through the analytical framework of 'abjection.' Indeed, since they are already within the state territory, and cannot be completely eliminated, undocumented migrants constitute themselves as 'abject' subjects. According to Julia Kristeva (1982), an 'abject' can be defined as a disrupting force that 'disturbs identity, system, order. What does not respect borders, positions, rules. The in-between, the ambiguous, the composite' (Kristeva 1982: 4).

Based on this reading, the political mobilisations of sex workers, which include undocumented migrants, can be analysed as movements of affirmation of abject subjectivities (Nyers 2003). In challenging the violent exclusionary logic of the sovereign state that denied their voice and political agency, these migrants are able to experiment new ways of 'being political' (Nyers 2008). Thus, the political commitments of migrant sex workers make room for the possibility of doing politics that do not reproduce the sovereign logic that has up to then relegated them to a depoliticised and abject field. By putting forward such claims, migrant sex workers have provoked abrupt ruptures within the conventional political regime, hitherto based on deprivation of rights for non-citizens. By allowing themselves to claim rights, they have reconfigured, therefore, the political space (McNevin 2006, 2011).

Finally, the mobilisation of migrant sex workers can be conceptualised as a policy of 'anti-identity' (Genova 2015). In fact, the undocumented immigrant sex workers are problematic subjects, as they are irregular in terms of their professional activity and mobility status. Their main political demand is not to be included in the current category of 'citizen' as it exists today, but rather to overturn the foundations of modern citizenship. In that sense, these insubordinate and unintelligible claims against the legal regime of citizenship could ultimately be interpreted as a claim to anti-identity.

\section{Final considerations}

This article has used the lens of gender to analyse the phenomenon of migration of sex workers, and its relations with and distinctions from the phenomenon of 'sex trafficking.' Feminist readings have challenged the traditional assumptions of International Relations theories, which so far have focused exclusively on the public sphere and on the role of statesmen. The purpose of feminist studies has been then to explore the mechanisms of gender construction, highlighting the social meanings attributed to the categories of masculinity and femininity.

This article relies on a typological approach that aims to clear some ground in the on-

going debate on the issues of prostitution, sex trafficking and migration of sex workers. It analysed not only the similarities and differences of radical, liberal, post-colonial, critical, postmodern and queer perspectives, but also stressed their theoretical cross-contribution as well as their conceptual limitations on migration and sex work. In other words, it explored the articulations between these different feminist approaches by examining the ways they may dialogue with, intersect, and confront one another. 
The first part of this article brought to light the 'sex war' between radical and liberal perspectives on the phenomena of prostitution, sex trafficking and migration of sex workers by emphasising their divergence when it comes to their conception of sexuality, sex workers' agency, and regulation of the sex work market.

The second part of this article highlighted the theoretical contributions of post-colonial and critical feminism on the issue of sex workers migration, emphasising their purpose of disrupting the oversimplified categorisations and dichotomous separations that have so drastically divided radical and liberal feminists in traditional literature. By integrating the multiple interactions between race/ethnicity, class and culture, these new approaches have contributed to a better understanding of the complexity of the link between migration and sex work.

The third and last part of this article addressed the contributions of postmodern feminism to the issues of prostitution and international migration of sex workers. The queer perspective developed with the crucial purpose of deconstructing every homogenising identity demarcation and opening up the path to new forms of flexible or negotiable identities. By questioning the social regulation of sexuality and the production of labels on sexes, the queer reading advocates for the diversity, difference and plurality of sexual identities. In addition, it has destabilised the boundaries and hierarchies which circumscribe the social meanings associated with the global mobility of migrants who work in the transnational sex industry.

In particular, the postmodern feminist perspective has analysed how conventional theories are grounded in a dichotomous structure that divides male from female, public from private sphere, or rationality from irrationality. The contemporary debate on the migration of sex workers does not constitute an exception, as it is permeated by multiple binary constructions. First/Third world, white/coloured, rich/poor, vulnerability/empowerment, innocence/conscience, sexual trafficking/voluntary prostitution, and forced migration/autonomous migration are examples of dualistic thoughts around which the postmodern feminist approach takes a stance.

The crucial purpose of postmodern feminism is precisely to undermine all fixed demarcations or homogeneous forms of categorisation in order to allow for the emergence of new practices of subjectivity, as well as new forms of flexible identities. Since individuals balance their 'self' with the constraints of their social environment, identities cannot be interpreted as strictly essentialist or socially constructed. Therefore, the identities of migrant sex workers are products of both the social structure in which they are inserted and of their individual agency itself. Sex workers are constituted and shaped by an extreme variation of identities, expressions, expectations and norms. 


\section{References}

Alles, Natália Ledur and Denise Cogo. 2017. 'Mídia e Migração Feminina (In)distinções entre trabalho sexual e tráfico de pessoas.' Périplos: Revista de Pesquisa sobre Migrações 2 (2): 1-17.

Andersen, Margaret L. 2005. 'Thinking about women: A quarter century's view.' Gender and Society 19 (4): 452.

Andrijasevic, Rutvica. 2004. Trafficking in Women and the Politics of Mobility in Europe. PhD Thesis, University of Utrecht, Netherlands.

2005. 'La traite des femmes d'Europe de l'Est en Italie. Analyse critique des représentations.' Revue européenne des migrations internationales 21 (1): 16.

Andrijasevic, Rutvica, Claudia Aradau, Jef Huysmans and Vicki Squire. 2012. 'European citizenship unbound: Sex work, mobility, mobilisation.' Environment and Planning D: Society and Space 30 (3): 497-514.

Aradau, Claudia, Jef Huysmans and Vicki Squire. 2011. 'Atos de cidadania europeia: uma sociologia política da mobilidade.' Contexto Internacional 33 (1): 179-208.

Augustin, Laura Maria. 2005. Sex at the Margins, Labour, Markets and the rescue Industry. London: Zed Books.

Bazzano, Ariana. 2016. 'O crime de tráfico de pessoas na justiça penal brasileira: uma leitura das sentenças sob as lentes de gênero.' In $10^{\circ}$ Encontro da Associação Brasileira de Ciência Política, Belo Horizonte.

Barry, Kathleen, Charlotte Bunch and Shirley Castley (eds). 1984. International Feminism: Networking against Female Sexual Slavery (Report of the Global Feminist Workshop to Organize Against Traffic in Women, Rotterdam, the Netherlands, April 6-15, 1983). New York: International Women's Tribune Centre.

. 1984. Female Sexual Slavery. New York: New York University Press. 1995. The Prostitution of Sexuality. New York: New York University Press.

Berman, Jacqueline. 2003. '(Un)popular strangers and crises (un)bounded: Discourses of sex-trafficking, the European political community and the panicked state of the modern state.' European Journal of International Relations 9 (1): 37-86.

Butler, Judith. 1993. Bodies That Matter: On the Discursive Limits of 'Sex.' New York: Routledge.

Chambers, Samuel. A. 2009. 'A queer politics of the democratic miscount.' Borderlands E-Journal 8 (2): $1-23$

Coalition Against Trafficking Women. 2011. At http://www.catwinternational.org/ [Accessed on 10 January 2018].

Creed, Barbara. 1994. 'Queer theory and its discontents: Queer desires, queer cinema.' In Norma Grieve and Ailsa Burns (eds), Australian Women: Contemporary Feminist Theory. Melbourne: Oxford University Press, pp. 151-164.

Doezema, Jo. 1995. Choice in Prostitution in Changing Faces of Prostitution. Helsinki: Union - The League of Finnish Feminists.

2004. ‘ ¡A crecer! La infantilización de las mujeres en los debates sobre tráfico de mujeres.' In Raquel Osborne (ed,) Trabajador@s del sexo - Derechos, migraciones y tráfico en el siglo XXI. Barcelona: Bellaterra, pp. 151-163. 
2011. 'Forced to choose: Beyond the voluntary vs. forced prostitution dichotomy'. In Global Sex Workers: Rights, Resistance and Redefinition, pp. 46-47.

Enloe, Cynthia. 2004. The Curious Feminist: Searching for Women in a New Age of Empire. Berkeley: University of California Press.

Gamson, Joshua and Dawne Moo. 2004. 'The sociology of sexuality: Queer and beyond.' Annual Review of Sociology 30: 47-64.

Genova, Nicholas. 2015. 'The queer politics of migration: Reflections on "illegality" and "incorrigibility."' Studies in Social Justice 4 (2): 101-126.

Global Alliance Against Trafficking in Women (GAATW). n.d. At http://www.gaatw.org/ [Accessed on 10 January 2018].

Halperin, David. 1995. M. Saint Foucault: Towards a Gay Hagiography. New York: Oxford University Press.

Hughes, Donna M. 2000. 'The Natasha Trade: The transnational shadow market of trafficking in women.' Journal of International Affairs 53 (2): 625-651.

Isin, Engin F. 2008. 'Theorizing acts of citizenship.' In Engin F Isin and Greg M Nielsen (eds), Acts of Citizenship. London: Palgrave Macmillan, pp. 15-43.

International Committee on the Rights of Sex Workers in Europe (ICRSE). 2005. The Declaration on the Rights of Sex Workers in Europe. Amsterdam: ICRSE.

Jahic, Galma and James O Finckenauer. 2005. 'Representations and misrepresentations of human trafficking.' Trends in Organized Crime 8 (3): 24-40.

Jeffreys, Sheila. 1997. The Idea of Prostitution. Melbourne: Spinifex.

ledge.

2005. The Industrial Vagina: The Political Economy of the Global Sex Trade. New York: Rout-

Kay, Corina. 1999. 'Is sex work queer?'. Social Alternatives 18 (3): 48-53.

Kempadoo, Kamala. 2005. 'Mudando o debate sobre o tráfico de mulheres.' Cadernos Pagu 25: 55-78.

Kempadoo, Kamala and Jo Doezema. 1998. Global Sex Workers: Rights, Resistance and Redefinition. New York: Routledge.

Kristeva, Julia. 1982. Powers of Horror: An Essay on Abjection. Trans. Leon S. Roudiez. New York: Columbia University Press.

Limoncelli, Stephanie A. 2009. 'The trouble with trafficking: Conceptualizing women's sexual labor and economic human rights.' Women's studies International Forum. 32: 261-269.

Mai, Nick. 2012. 'Embodied cosmopolitanisms: The subjective mobility of migrants working in the global sex industry.' Gender, Place and Culture 20(1): 1-18.

2014. 'Between embodied cosmopolitism and sexual humanitarianism: The fractal mobilities and subjectivities of migrants working in the sex industry' In Lisa Anteby-Lemini, Virginie Baby-Collin and Sylvie Mazzella (eds), Borders, Mobilities and Migrations. Perspectives from the Mediterranean in the 21st Century. Brussels: Peter Lang, pp. 175-192.

Mandelbrot, Benoît. 1982. The Fractal Geometry of Nature. New York: Freeman.

Mayorga, Claudia. 2011. 'Cruzando fronteiras: prostituição e imigração.' Cadernos Pagu 37: 323-355.

McClintock, Anne. 1993. 'Introduction: Sex workers and sex work.' Social Text, Special Issue on Sex work, Social Text 34. Durham: Duke University Press. 
McNevin, Anne. 2006. 'Political belonging in a neo-liberal era: The struggle of the sans papiers' Citizenship Studies 10 (2): 135-151.

2011. Contesting Citizenship: Irregular Migrants and New Frontiers of the Political. New York: Columbia University Press.

2013. 'Ambivalence and citizenship: Theorizing the political claims of irregular migrants.' Millennium: Journal of International Study 41 (2): 182-200.

Mezzadra, Sandro. 2011. 'The gaze of autonomy. Capitalism, migration, and social struggle.' In V Squire (ed), The Contested Politics of Mobility: Border Zones and Irregularity. London: Routledge, pp. 121-143.

Mohanty, Chandra Talpade. 1991. 'Under Western eyes: Feminist scholarship and colonial discourses.' In Chandra Mohanty, Ann Russo and Lourdes Torres (eds), Third World Women and the Politics of Feminism. Bloomington: Indiana University Press, pp. 56.

Nyers, Peter. 2003. 'Abject cosmopolitanism: The politics of protection in the anti-deportation movement'. Third World Quarterly 24 (6): 1069-1093.

2008. 'No one is illegal between city and nation.' In Engin F Isin and Greg M Nielsen (eds), Acts of Citizenship. London: Zed Books, pp. 160-181.

Outshoorn, Joyce. 2004. The Politics of Prostitution: Women's Movements, Democratic States, and the Globalization of Sex Commerce. Cambridge: Cambridge University Press.

Papadopoulos, Dimitris, Niamh Stephenson and Vassilis Tsianos. 2008. Escape Routes. Control and Subversion in the 21st Century. London: Pluto Press.

Pateman, Carole. 1988. The Sexual Contract. Stanford: Stanford University Press.

Pelúcio, Larissa. 2009. “'Sin papeles” pero con glamur: Migración de travestis brasileñas a España.' Vibrant - Virtual Brazilian Anthropology 6 (1): 170-197.

Pendleton, Eva. 1997. 'Love for sale. Queering heterosexuality'. In Jill Nagle (ed), Whores and Other Feminists. New York: Routledge, pp. 73-82.

Perkins, Roberta. 1991. Working Girls. Canberra: Australian Institute of Criminology.

Pickup, Francine. 1998. 'Deconstructing trafficking in women: The example of Russia.' Millennium: Journal of International Studies 27 (4): 995-1022.

Peterson, V Spike and Anne Sisson Runyan. 1999. Global Gender Issues. Boulder: Westview Press.

Philips, Chas. 2009. 'Difference, disagreement and the thinking of queerness.' Borderlands E-Journal 8 (2): 1-17.

Piscitelli, Adriana. 2007. 'Corporalidade em confronto: brasileiras na indústria do sexo na Espanha.' Revista Brasileira de Ciências Sociais 22 (64): 17-32.

2013. Trânsitos: brasileiras nos mercados transnacionais do sexo. Rio de Janeiro: Eduerj.

Read, Kate W. 2013. 'Queering the brothel: Identity construction and performance in Carson City, Nevada.' Sexualities 16 (3-4): 467-486.

Shrage, Laurie. 1997. Moral Dilemma of Feminism. Prostitution, Adultery and Abortion. New York: Routledge.

Silva, Ana Paula and Thaddeus Blanchette. 2005. 'Nossa Senhora da Help: sexo, turismo e deslocamento transnacional em Copacabana.' Cadernos Pagu 25: 249-280. 
Silva, Ana. Paula, Thaddeus Blanchette and Andressa Raylane Bento. 2010. 'Cinderella deceived: Analysing Brazilian myth regarding trafficking in persons.' Vibrant 10 (2): 377-419.

Squire, Vicki. 2009. The Exclusionary Politics of Asylum. Basingstoke: Palgrave.

Tickner, J Ann. 2001. Gendering world Politics. New York: Columbia University Press.

UN Convention Against Transnational Organized Crime. 2000. Protocol to Prevent, Suppress and Punish Trafficking in Persons, Especially Women and Children At http://www.unodc.org/unodc/en/ human-trafficking/index.html?ref=menuside [Accessed on 8 January 2018].

Weber, Cynthia. 2004. 'Queer International Relations, from queer to Queer IR.' International Studies Review 16: 596-622.

Weitzer, Ronald. 2007. 'The social construction of sex trafficking: Ideology and institutionalization of a moral Crusade.' Politics and Society 35 (3): 447-475.

Wijers, Marjan. 1998. 'Women, labor and migration: The position of trafficked women and strategies for support.' In Kamala Kempadoo and Jo Doezema (eds), Global sex workers: Rights, resistance and redefinition. New York: Routledge, pp. 69-78.

Zalewski, Marysia. 2000. Feminism After Postmodernism: Theorising Through Practice. London: Routledge.

\section{About the author}

Charlotte Valadier is undertaking a $\mathrm{PhD}$ in International Relations at the Pontifícia Universidade Católica do Rio de Janeiro (PUC-Rio). She gained a master's degree in Geopolitics and International Relations at the Institut de Sciences Politiques of Toulouse, in France. As an expert on issues related to prostitution, sex trafficking and migration of sex workers, she has recently published 'The migrant sex worker in Europe: Constructing and governing a threat' in the journal Mural Internacional, and 'The trafficked woman's body: Territory of political claims and disputes' in the journal Bagoas. She is currently developing $\mathrm{PhD}$ research on the articulation of migration and prostitution phenomena using the particularities of the experiences of Brazilian sex workers in France. 


\section{Migração e Trabalho Sexual por uma Perspectiva de Gênero}

Resumo: As trajetórias de migração e prostituição estão embebidas em representações de corpo, gênero, sexo e sexualidade. Este artigo procura entender a articulação entre migração e trabalho sexual pelas lentes do gênero. Para este fim, este artigo conta com uma abordagem tipológica que objetiva clarear os caminhos no debate destas questões de prostituição, tráfico sexual e migração de trabalhadores sexuais. Explora a contribuição teórica cruzada, bem como as limitações conceituais das perspectivas feministas radicais, liberais, pós-coloniais, críticas e pós-modernas sobre as questões da prostituição, mobilidade dos profissionais do sexo e tráfico sexual. Dá especial atenção às contribuições da leitura feminista pós-moderna, especialmente destacando como ela desafiou as teorias feministas convencionais, até então baseadas em estruturas dualistas. De fato, a abordagem feminista pós-moderna se posiciona contra as dicotomias simplistas como Primeiro/Terceiro Mundo, passividade/agência, vulnerabilidade/empoderamento, inocência/consciência, tráfico sexual/prostituição voluntária ou 'vítima traficada'/'trabalhador do sexo autônomo.' Como tal, o feminismo pós-moderno rompe todas as demarcações fixas e formas homogêneas de categorização nas quais as teorias feministas dominantes foram baseadas, permitindo assim o surgimento de novas práticas de subjetividade, bem como novas formas de identidades flexíveis.

Palavras-chave: Migração; Trabalho Sexual; Tráfico Sexual; Gênero; Feminismo Pós-moderno.

Received on 15 January 2018, and approved for publication on 29 August 2018. 